\title{
Characterization of the national and foreign tourist who visits the city of La Serena, Chile
}

\section{Caracterización del turista nacional y extranjero que visita la ciudad de La Serena, Chile}

\author{
Sebastián Araya-Pizarro ${ }^{1 *}$, Manuel Álvarez Cortés² \\ ${ }^{1}$ Magíster en Liderazgo, Dirección Estratégica y Comunicación en las Organizaciones, Departamento de Ciencias Económicas y Empresariales, Universidad de La Serena, La Serena, Chile \\ ${ }^{2}$ Magíster en Liderazgo, Dirección Estratégica y Comunicación en las Organizaciones, Departamento de Ciencias Económicas y Empresariales, Universidad de La Serena, La Serena, Chile \\ *Corresponding author: sarayaQquserena.cl
}

\section{ABSTRACT}

The research analyzes the profile of the national and foreign tourists visiting a recognized destination of Chile: $L a$ Serena. Based on a field study applied to 920 tourists, their sociodemographic, behavioral, motivational and satisfaction attributes are contrasted. The results reveal a tourist of homogeneous demographic qualities, who travels to the area motivated by the desire to disconnect from the everyday life and by the tourist reputation of the city. The main differences between the types of tourists are found in the socioeconomic level and behavioral aspects of travel such as the planning time, expenses and the use of internet resources. Also, a high degree of visitors satisfaction was found based on the beauty of the city, the hospitality of the residents and the quality of the gastronomy. While, in the other hand, the public transport service, the guide and tourist information available and price-quality relationship are the least valued attributes. It concludes, in regarding to the need to enhance the tourism in the area by generating tourist products according to the particular profile of the visitor and their satisfaction determinants.

Keywords: tourist profile, segmentation variables, tourist attributes, tourist satisfaction, La Serena (Chile)

\section{RESUMEN}

La investigación analiza el perfil del turista nacional y extranjero que visita la ciudad de La Serena: reconocido destino turístico de Chile. En base a un estudio de campo aplicado a 920 turistas, se contrastan sus características sociodemográficas, conductuales, motivacionales y atributos de satisfacción. Los resultados develan un turista de cualidades demográficas homogéneas, que viaja a la zona impulsado por el ánimo de desconectarse de lo cotidiano y por la reputación turística de la ciudad. Las principales diferencias entre los tipos de turistas, se hallan en el nivel socioeconómico y aspectos comportamentales de viaje como el tiempo de planeación, gasto registrado y uso de recursos de internet. Se encontró, además, un alto grado de conformidad de los visitantes basado en la belleza de la ciudad, la hospitalidad de los residentes y la calidad de la gastronomía. Mientras que el servicio de transporte público, la guía e información turística disponible y la relación calidad-precio son los atributos menos valorados. Se concluye respecto de la necesidad de potenciar el turismo de la zona mediante la generación de productos turísticos acordes al perfil particular del visitante y de sus determinantes de satisfacción.

Palabras clave: perfil del turista, variables de segmentación, atributos turísticos, satisfacción del turista, La Serena (Chile) 


\section{INTRODUCTION}

For many years tourism has become an economic key development pole for countries, especially for developing nations (Orgaz \& Moral, 2016; Osuna, Castillo, \& López-Guzmán, 2011). Nowadays, it is recognized as an economic sector with a strong power of job opportunities, foreign exchange and encourage investments and the economic growth (Schulte, 2003).

Therefore, tourist satisfaction becomes a crucial topic and a main subject in the field of the tourism research. Besides increasing the possibility of the visitor return, it influences positively the recommendation of the tourist destination, generating a multiplier effect becoming into a greater frequency of visits and in the strengthening of loyalty to the tourist destination (Fernández \& Narváez, 2012; Oliveira, 2011; Weaver, Weber, \& Mccleary, 2007) which also leads to the strengthening of the competitiveness of the destination and a greater economic growth and well-being for the local population (Webster \& Ivanov, 2014).

In this context, the knowledge of the visitor's profile represents a fundamental aspect, whose particular characterization is decisive for the elaboration of a competitive tourist offer and the offering of a quality service based on those determining factors of their satisfaction and loyalty (criteria and attributes of value). Therefore, based on the market segmentation and considering the aspects related to the sociodemographic and consumer behavior profile, a more effective tourist destination management and promotion process can be developed (Solís-Radilla, Hernández-Lobato, \& Villagómez-Méndez, 2016).

La Serena, for its part, is one of the main tourist destinations of Chile (Levy \& Arce, 2016; Servicio Nacional de Turismo, 2018b). Located in the IV Region of Coquimbo, it's an area that is characterized by the architectural heritage of the city, the quality of its beaches and the identity of its gastronomy, based on seafood and the production of distillates such as pisco (Chilean drink with designation of origin, whose highest production, $90 \%$, is generated in the area) and fruit concentrates (such as papaya). Only, in terms of hosting, during March 2019, the region reported 51,215 visitors, including passengers of Chilean residence $(46,830)$ and foreigners $(4,385)$, confirming, on the one hand, the importance of the city as a tourist destination in Chile, and on the other hand, the potential of the tourism industry for the socioeconomic development of the terri- tory. However, in spite of the favorable conditions that the area presents, it has not been able to establish an effective competitive offer that reflect the arrival numbers of visitors into higher incomes and allows to take advantage of the historical and heritage wealth of the city. So, in a similar way occurred in Chile, it has not yet been capitalized on the high influx of international tourists arriving in the Region (similar to other Latin American tourist destinations), capturing only about $50 \%$ of the average expense of tourists visiting other countries like Brazil or Peru (Servicio Nacional de Turismo, 2017b, 2017a).

The objective of this article is to present the results of a fieldwork developed in the city of La Serena, Chile, which involves the socio-demographic profile of visitors, the preparation of the trip, the motivations of these tourists and the rating made for different attributes of satisfaction, based on their origin (national and foreign). To achieve this purpose, the article is organized, after this introduction, in four sections. First, it is described the geographical area of study. Second, it is presented the research methodology. Third, the main findings of the work are shown and discussed. And finally, the conclusions and the reference bibliography are summarized.

\section{STUDY AREA}

La Serena is a commune and a historic city in the north of Chile. It is the capital of the IV Region of Coquimbo. It is part of the province of Elqui and limits to the south with Coquimbo and Andacollo communes, to the north with La Higuera commune, to the west with the Pacific Ocean and to the east with Vicuña commune. It was founded in 1544, during the first years of the Spanish conquest period, becoming the third oldest city in Chile after the national capital, Santiago. To add, it constitutes with the port city of Coquimbo, in the most important conurbation of the Region, positioning itself as the fourth most important urban area in the country. According to the 2017 Census data, the commune has a population of 221,054 inhabitants, which represents an increase of $38 \%$ compared to the 2002 Census (Biblioteca del Congreso Nacional de Chile, 2017).

The city of La Serena owns a unique architectural construction with a preserved neocolonial style characterized by its balconies, squares and various centuries old stone churches. There are 21 national historical monuments between palaces, churches, houses and buildings and its historic center was declared a national monument in 1981. 


\section{RIAT}

The main tourist places of La Serena are concentrated on the seaside (Avenida del Mar and Faro Monumental), in the historic center (Route of the five Limestone Churches: Iglesia Catedral, Iglesia San Francisco, Iglesia Santo Domingo, Iglesia San Agustín and Iglesia La Merced), in the viewpoints (Mirador Santa Lucía, Mirador Campus Andrés Bello at the Universidad de La Serena and Mirador Av. Pedro Pablo Muñoz), in the museums

(Casa Museo Gabriel González Videla, Museo Arqueológico, Museo Sala de Arte Religioso, Museo al Aire Libre, Museo Mineralógico Ignacio Domeyko, Museo Colonial Iglesia San
Francisco), parks (Parque Pedro de Valdivia, Parque Gabriel Coll, Jardín Japonés), houses and city buildings (Casa Carmona, Casa Herreros, Casa Chadwick, Edificio Consistorial, Ilustre Municipalidad de La Serena, Plaza de Armas, La Recova, Edificio Isabel Bongard, Casa Jiliberto y Centro de Interpretación del Patrimonio Religioso, Iglesia Santa Inés). Check Figure 1. In this way, the city of La Serena has a great potential in the tourist cultural development which has been reflected in the realization of international music, film, theater and dance festivals, as well as different cultural events (SECPLAN, 2015; Servicio Nacional de Turismo, 2018a).

Figure 1. Tourist places of the city of La Serena

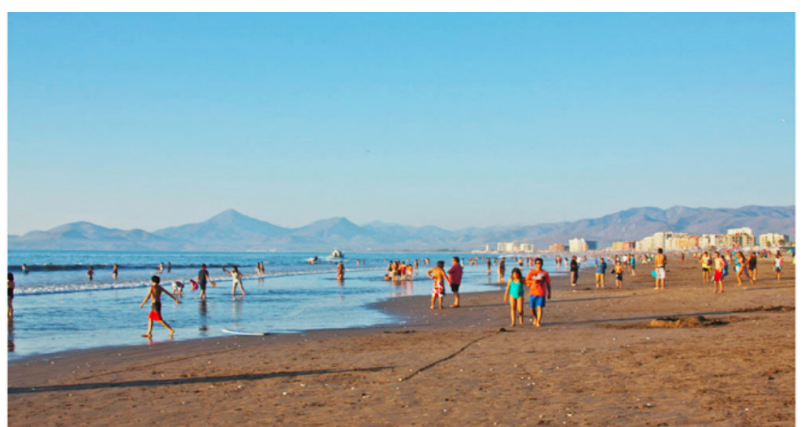

Avenida del Mar de La Serena

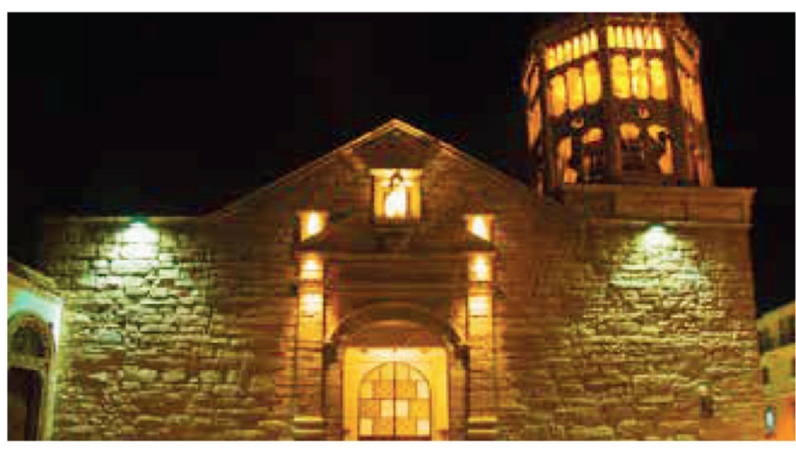

Iglesia Santo Domingo

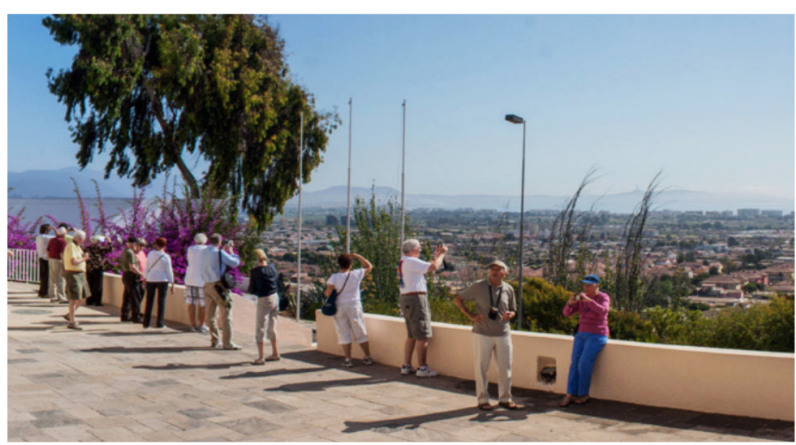

Mirador de la Universidad de La Serena

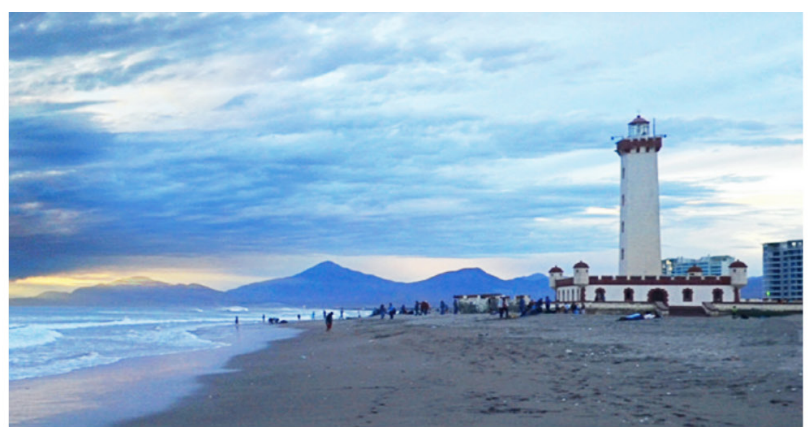

Faro Monumental

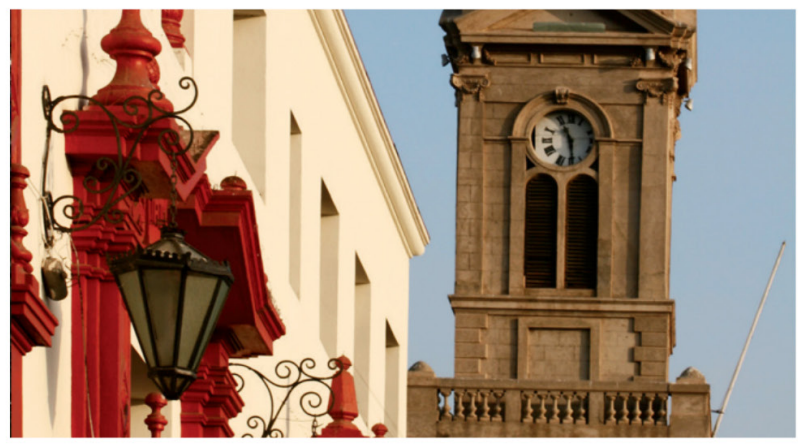

Centro Histórico de La Serena

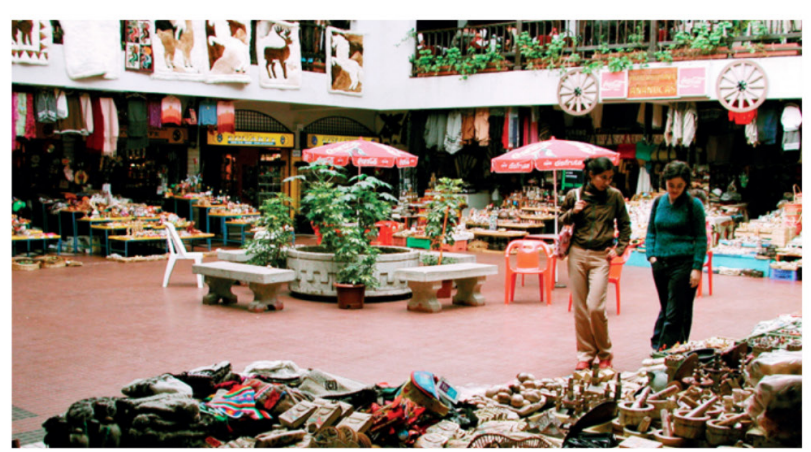

Plaza de Abastos “La Recova”

Source: Servicio Nacional de Turismo (2018a). 
Avenida del Mar offers to La Serena a special attraction placing it as an international sun and beach destination. Its extensive coastline, framed on a 7-kilometer long waterfront, is bordered by the most exclusive tourist infrastructure in the region. It shows a wide variety of alternatives for hosting services (such as hotels, apart hotels, cabins, residential, among others), restaurants, pubs, bars and discos, which contribute significantly to the tourist image of the place, becoming the Avenida del Mar, in the center of Bohemian Serene life and one of the most attractive places for tourism and entertainment. There are 12 recognized beaches from north to south: El Faro, Los Fuertes, Mansa, Blanca, La Barca, 4 Esquinas, La Marina, El Pescador, El Corsario, Hipocampo, Las Gaviotas and Canto del Agua. All are suitable for swimming and water sports excepts El Faro beach.

All this explains that tourism has become one of the most important economic activities of the city whose population is estimated to duplicate during the summer season (SECPLAN, 2015; Servicio Nacional de Turismo, 2018a). Nowadays, La Serena lives in a marked development based on its various attractions and geographical, climatic, natural (beaches, parks, valleys, etc.) and cultural (museu$\mathrm{ms}$, architecture, crafts, folklore, etc.), placing it as one of the most important tourist destination in Chile and also, one of the places with the highest quality of life in the country (Visión Humana, 2018).

\section{METHODOLOGY}

The study used a quantitative, non-experimental design, descriptive and cross-sectional approach characterizing the profile of the visitor of the city of La Serena based on sociodemographic, behavioral, motivational and satisfaction characteristics.

The sample included 920 participants and the size was computed by a proportional sampling of infinite population $(N>100,000)$, with a margin of error of $3.217 \%$, a confidence level of $95 \%$ and a heterogeneity of $50 \%$.
The data was collected through an ad hoc survey, based on the work of Muñoz, Carvache-Franco, Torres-Naranjo \& López-Guzmán (2018) and applied in person during the summer season of the year 2019 (December-January). The data collection instrument was a questionnaire of 38 total questions divided into five sections: (1) sociodemographic profile of the tourist, (2) behavioral characteristics, (3) motivational aspects, (4) level of visitor's compliance and (5) assessment of the attributes of the destination. The detail of each valid questionnaire item is summarized in Table 1.

The reliability of the instrument (Likert scale) was measured through Cronbach's alpha coefficient that reveled appropiate results for the three dimensions of interest $(\boldsymbol{\alpha}>$ .70), being 0.96 for the level of satisfaction, 0.71 for the motivational aspects and of 0.83 for the assessment of the attributes of the destination.

The information collected was statistically analyzed through the design of frequency tables (absolute and relative), the calculation of descriptive statistics of central tendency and dispersion, also to the execution of inferential tests normality of the data (Kolmogorov-Smirnov test), homogeneity of variances (Levene's test), comparison of means ( $T$ test and Analysis of Variance), correlation tests (Pearson's $\mathrm{R}$ coefficient) and association of nominal variables (Chi-square test). All the results were obtained through the IBM SPSS software for Windows.

\section{RESULTS AND DISCUSION}

\section{Sociodemographic aspects}

In general, tourists visiting the city of La Serena have a homogeneous socio demographic profile. They are women (52\% average) and men (48\% average) under 40 years old (61\% average), with an undergraduate education level (53\% average), economically active (73\% average) and monthly income below CLP 1,200,000 (85\% average). Check Table 2. 
Table 1: Description of the questionnaire content

\begin{tabular}{|c|c|c|c|}
\hline Section & Item & Questions & Type \\
\hline Socio-demographic profile & 6 & $\begin{array}{l}\text { Sex, Age, Origin, Educational level, } \\
\text { Profession and Monthly income }\end{array}$ & $\begin{array}{l}\text { Closed multiple-choice } \\
\text { questions }\end{array}$ \\
\hline Behavioral characteristics & 10 & $\begin{array}{l}\text { Who motivated the trip, Planning time, Type } \\
\text { of accommodation, Type of companions, } \\
\text { Expenditure level, Duration of the visit*, } \\
\text { Preferred local product, Means of transport to } \\
\text { enter the city, Internet resources used for } \\
\text { preparation of the trip, online services contracted. }\end{array}$ & $\begin{array}{l}9 \text { closed questions excluding } \\
\text { multiple-choice and } 1 \\
\text { open question }(*) .\end{array}$ \\
\hline Motivational aspects & 7 & $\begin{array}{l}\text { To know new places, To get away from the } \\
\text { traditional, To take advantage of its economic } \\
\text { convenience, To taste its gastronomy, To know its } \\
\text { historical wealth, To check its tourist reputation, } \\
\text { To attend its cultural events }\end{array}$ & $\begin{array}{l}\text { Likert scale }(1=\text { Not at all } \\
\text { influential to } 5=\text { Extremely } \\
\text { influential) }\end{array}$ \\
\hline Level of conformity & 3 & $\begin{array}{l}\text { Repeat of the visit, Recommendation of the } \\
\text { destination and Level of total satisfaction }\end{array}$ & $\begin{array}{l}\text { Likert scale }(1=\text { total } \\
\text { disagreement to } 5=\text { total } \\
\text { agreement })\end{array}$ \\
\hline Attributes of the destination & 12 & $\begin{array}{l}\text { Beauty of the city, Local hospitality, Cleanliness } \\
\text { of the area, Public safety, Public transport, Tourist } \\
\text { information, Value for money, Gastronomy, Tour } \\
\text { guides, Hosting, Restaurant-bar service, } \\
\text { Complementary leisure offer }\end{array}$ & $\begin{array}{l}\text { Likert scale }(1=\text { very } \\
\text { bad to } 5=\text { very good })\end{array}$ \\
\hline
\end{tabular}

Source: Prepared by the authors. 
Table 2: Sociodemographic characteristics of national $(n=595)$ and foreign $(n=325)$ tourists, in percentage

\begin{tabular}{|c|c|c|c|}
\hline Criteria & Variables & National (\%) & Foreign (\%) \\
\hline \multirow[t]{2}{*}{ Sex } & Man & 48.4 & 48.0 \\
\hline & Women & 51.6 & 52.0 \\
\hline \multirow[t]{6}{*}{ Age } & Less than 30 years old & 35.6 & 33.2 \\
\hline & Between 30 and 39 years old & 24.0 & 29.2 \\
\hline & Between 40 and 49 years old & 20.2 & 19.7 \\
\hline & Between 50 and 59 years old & 11.9 & 12.6 \\
\hline & Between 60 and 69 years old & 6.6 & 4.0 \\
\hline & Over 69 years old & 1.7 & 1.2 \\
\hline \multirow[t]{5}{*}{ Monthly income } & Less than CLP 300001 & 29.1 & 18.2 \\
\hline & Between CLP 300001 and CLP 700000 & 29.4 & 33.2 \\
\hline & Between CLP 700001 and CLP 1200000 & 27.1 & 32.3 \\
\hline & Between CLP 1200001 and CLP 2500000 & 11.4 & 12.0 \\
\hline & Over CLP 2500000 & 3.0 & 4.3 \\
\hline \multirow[t]{4}{*}{ Educational level } & Primary & 2.9 & 1.5 \\
\hline & High school & 31.8 & 25.2 \\
\hline & Undergraduate & 51.8 & 55.1 \\
\hline & Postgraduate & 13.6 & 18.2 \\
\hline \multirow[t]{7}{*}{ Profession or occupation } & Student & 20.8 & 12.9 \\
\hline & Independent worker & 14.6 & 17.2 \\
\hline & Dependent worker & 36.8 & 40.6 \\
\hline & Public official & 12.6 & 7.7 \\
\hline & Housewife & 6.4 & 7.4 \\
\hline & Businessman & 4.9 & 12.0 \\
\hline & Does not work or study & 3.9 & 2.2 \\
\hline
\end{tabular}

Source: Prepared by the authors.

However, the analysis of the results referring to socioeconomic characteristics according to the origin of the tourist, revealed significant associations about the variables: monthly income $[\chi 2(4, \mathrm{~N}=920)=13.995, \mathrm{p}=.007]$, educational level $[\chi 2(3, N=920)=7.858, p=.049]$ and profession or occupation $[\chi 2(6, N=920)=30.329, p<.001]$, showing that the foreign tourist has a higher socioeconomic level than national tourist, that is to say, is more educated, has a better employment situation and has greater monetary income.

Regarding demographic characteristics such as sex and age, no relevant associations were found, demonstrating their independence in relation to the nationality of the tourist and the commonality of these characteristics in the visitor's profile, which is even possible to observe in other studies related to the description of the tourist (Sandoval, Ordoñez, \& Noblecilla, 2018; Yumisaca, Mendoza, \& Villón, 2017).

\section{Behavioral aspects of the tourist}

National tourists declare having been motivated to travel to the city of La Serena, mainly by family and friends (62\%) or with the intention of repeat their visit (19\%). On average, they record a stay of between 6 and 10 days (63\%) and an expense of between CLP 150,000 and CLP 400,000 
(43\%). Most of them were hosted in houses / apartments rented (35\%) or family (30\%), planning their trip less than four weeks in advance (66\%). Regarding the use of internet resources (social networks, maps, hotel reservations, travel websites, information pages, etc.), the majority used only one service for the planning of the visit (46\%) and, during their stay in the city, they contracted online services (55\%), especially for hosting (36\%), transportation (12\%) and tour (4\%).

On the other hand, foreign tourists were motivated to visit La Serena by family and friends (45\%) and to repeat their trip (27\%), registering, on average, a duration of more than 15 days of stay (52\%), with an expense of between CLP 150,000 and CLP 800,000 (67\%). They stayed mostly in rented houses / apartments (39\%) and in hotels (21\%), planning their trip at least 4 weeks in advance (51\%). To plan their visit, most visitors used one (49\%) or more (36\%) internet resources and, during their stay, hired online services for hosting (51\%) and transportation (11\%). Check Table 3.
From Table 3 it's possible to note, in relative terms, that foreign tourists unlike national tourists: (i) They are more influenced in their travel decision (motivation) through the internet and social networks (17\% versus $9 \%$ ); (ii) They have longer stays, exceeding 10 days (64\% versus 18\%); (iii) They spend more during their visit, with amounts over CLP 400,000 (51\% versus 36\%); (iv) They use hotels more as a means of accommodation (21\% versus $12 \%$ ); (v) Plan their trip with more time, exceeding 4 weeks (51\% versus 34\%); (vi) They use more internet resources to prepare their trip (36\% versus $25 \%$ ) and (vii) They contracted more online services during their visit (74\% versus $55 \%$ ).

The analysis of independence between the behavioral variables and the origin of the tourist revealed highly significant associations for all the criteria under study $(p<.001)$, with the exception of the item with who attended the city $[\chi 2(3, N=920)=5.901, p=.117]$, which confirms the previous results.

Table 3: Behavioral characteristics of national $(n=595)$ and foreign $(n=325)$ tourists, in percentage

\begin{tabular}{llll}
\hline Criteria & Variables & National (\%) & Foreign (\%) \\
\hline Source of tourist motivation & Friends or family & 61.8 & 45.2 \\
& Previous experience & 18.8 & 26.5 \\
& Internet and social networks & 9.4 & 16.9 \\
& Other & 9.9 & 11.4 \\
\hline Duration of the visit & Less than 5 days & 19.0 & 4.9 \\
& Between 6 and 10 days & 62.7 & 31.3 \\
& Between 11 and 15 days & 12.4 & 11.4 \\
& Over 15 days & 5.9 & 52.4 \\
\hline Approximate expense of the visit & Less than CLP 150 000 & 21.2 & 13.5 \\
& Between CLP 150 000 and CLP 400 000 & 42.9 & 36.0 \\
& Between CLP 400 001 and CLP 800 000 & 24.2 & 30.8 \\
\hline Who did he visit the city with? & Más de CLP 800 000 & 11.8 & 19.7 \\
\hline Type of hosting used & Alone & 7.2 & 6.2 \\
& With friends & 19.0 & 25.5 \\
& With family & 68.1 & 64.0 \\
& Other & 5.7 & 4.3 \\
\hline & Department / House Rented & 35.1 & 39.4 \\
& Family House & 30.4 & 11.1 \\
& Hotel / Apart Hotel & 11.6 & 20.9
\end{tabular}




\begin{tabular}{llll} 
Trip Planning Time & Between 2 and 3 weeks & 66.2 & 49.5 \\
& Between 4 and 6 weeks & 23.9 & 32.3 \\
& Over 6 weeks & 9.9 & 18.2 \\
\hline Internet resources for travel preparation & None & 29.6 & 15.1 \\
& One & 45.9 & 48.6 \\
& Two or more & 24.5 & 36.3 \\
\hline Online services contracted during the visit & Housing & 36.3 & 50.8 \\
& Restaurant & 2.2 & 2.8 \\
& Tour & 4.0 & 8.6 \\
& Transport & 11.9 & 10.5 \\
& Other & 1.0 & 1.5 \\
& None & 44.5 & 25.8 \\
\hline
\end{tabular}

Source: Prepared by the authors.

It's interesting to note the findings related to the use of the internet and social networks, where it's appreciated that it has an integral influence on the tourist visit process. First, it motivates the intention to visit, then, it participates in the trip planning, and finally, it intervenes through the contracting of online services during the stay itself. This denotes the growing importance of the Internet for the visitor and the potential it has as a communication tool for the promotion and projection of the tourist image of the destinations and their tourist attractions (Hidalgo-Alcázar, Sicilia y De Maya, 2015; López, Verdesoto y López, 2017). Motivational aspects of the tourist

Table 4 shows that the motivational aspects of national and foreign tourists coincide between the main reason for traveling (disconnecting from everyday life) and the less relevant ones (attending cultural events and knowing their historical wealth). However, the foreign tourist shows a greater impulse to know new places, while the national tourist to take advantage of the economic accessibility of the city. In this way, it is obtained that foreign tourists travel to the city of La Serena with the aim of disconnecting from the traditional, the desire to know new places and the tourist reputation of the city (image and global perception of the destination). While national tourists do this to disconnect from the everyday life, take advantage of the economic accessibility of the area and the city's tourist reputation. Foreseeable results, considering that people with lower incomes are more sensitive to the price of the service (income elasticity) prioritizing in their decision of consumption the monetary factors (Morales, Arévalo, Padilla, \& Bustamante, 2018).
The dependence analysis of the motivational aspects of domestic and foreign tourists revealed significant associations only in relation to the desire to know new places $[\chi 2$ $(4, \mathrm{~N}=920)=22.13, \mathrm{p}<.001]$. In particular, the foreign tourist indicated a higher proportion of conformity with this assessment in contrast to the national tourist (49\% versus 35\%). In this sense, Araújo \& De Sevilha (2017), indicates that this reason is associated to the desire of tourists to learn and discover new things, which shows that the visitor, instead of committing to a specific tourist destination, focuses in achieving a new experience on each travel or get similar experiences in the new destinations of travel (experiential loyalty).

It should be noted when national and foreign tourists were consulted on the gastronomic local product preferred, they agreed to highlight the fish and seafood (35\% foreign and $32 \%$ Chilean), however, the preferences expressed for the rest of the products showed significant differences $[\chi 2$ $(6, N=920)=33.83, p<.001]$. For example, the case of papaya ( $22 \%$ versus $14 \%$ ) and goat cheese ( $14 \%$ versus $7 \%$ ) more valued by the national tourist or the case of wine, widely, more appreciated by the foreign tourist (19\% versus 9\%). Check Figure 2.

Finally, the low percentages registered in the interest to know the historical wealth of the city and to attend cultural events, aspects considered characteristic of the city, call the attention to the need to design communication strategies that improve the positioning of the city of La Serena based on the promotion of its cultural historical heritage. 
Table 4: Motivations of national $(n=595)$ and foreign $(n=325)$ tourists, in percentage

\begin{tabular}{|c|c|c|c|c|c|c|}
\hline Item & Origin & $\begin{array}{l}\text { Not at all } \\
\text { influential }\end{array}$ & $\begin{array}{c}\text { Slightly } \\
\text { influential }\end{array}$ & $\begin{array}{l}\text { Somewhat } \\
\text { influential }\end{array}$ & $\begin{array}{c}\text { Very } \\
\text { influential }\end{array}$ & $\begin{array}{l}\text { Extremely } \\
\text { influential }\end{array}$ \\
\hline \multirow[t]{2}{*}{ To get know new places } & National & 5.2 & 6.9 & 17.6 & 35.8 & 34.5 \\
\hline & Foreign & 4.0 & 2.8 & 12.6 & 32.0 & 48.6 \\
\hline \multirow[t]{2}{*}{ To get away from the traditional } & National & 0.8 & 1.7 & 8.6 & 30.6 & 58.3 \\
\hline & Foreign & 1.5 & 1.2 & 8.0 & 31.1 & 58.2 \\
\hline \multirow{2}{*}{$\begin{array}{l}\text { To take advantage of its } \\
\text { economic convenience }\end{array}$} & National & 2.9 & 4.5 & 20.7 & 32.4 & 39.5 \\
\hline & Foreign & 4.6 & 3.4 & 20.6 & 38.2 & 33.2 \\
\hline \multirow[t]{2}{*}{ To taste its gastronomy } & National & 4.4 & 6.6 & 21.8 & 33.8 & 33.4 \\
\hline & Foreign & 2.5 & 6.2 & 18.8 & 36.3 & 36.3 \\
\hline \multirow[t]{2}{*}{ To know its historical wealth } & National & 7.1 & 13.1 & 28.9 & 28.9 & 22.0 \\
\hline & Foreign & 8.0 & 8.6 & 26.5 & 31.7 & 25.2 \\
\hline \multirow[t]{2}{*}{ To check its tourist reputation } & National & 3.7 & 3.4 & 18.7 & 43.5 & 30.8 \\
\hline & Foreign & 2.2 & 2.5 & 13.8 & 44.9 & 36.6 \\
\hline \multirow[t]{2}{*}{ To attend its cultural events } & National & 25.0 & 16.3 & 25.7 & 19.5 & 13.4 \\
\hline & Foreign & 25.5 & 13.8 & 25.8 & 16.6 & 18.2 \\
\hline
\end{tabular}

Source: Prepared by the authors.

Figure 2: Proportion of national $(n=595)$ and foreign $(n=325)$ tourists according to their preferred gastronomic product

$$
\text { — Foreign tourist } \quad \text { National tourist }
$$

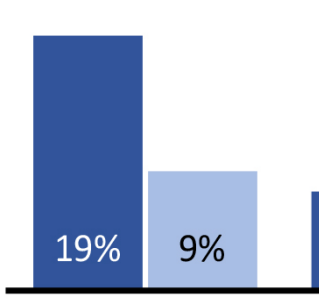

Wine

Foreign tourist National tourist

Source: Prepared by the authors. 


\section{Tourist Conformity}

In general, tourists showed high and homogeneous levels of satisfaction (Table 5). More than $90 \%$ of the survey respondents said to be satisfied with their visit, willing to return to the city and recommend it as a tourist destination. Also, even when it is appreciated that foreign visitors present a slightly higher assessment than the national tourist in the three criteria of interest, these did not show to be statistically significant differences (test of means with a level of significance of $5 \%$ ).

Table 5: Levels of satisfaction, recommendation and repetition of travel by national $(n=595)$ and foreign $(n=325)$ tourists, in percentage

\begin{tabular}{llcc}
\hline Criteria & Variable & $\begin{array}{c}\text { National } \\
\text { (\%) }\end{array}$ & $\begin{array}{c}\text { Foreign } \\
\text { (\%) }\end{array}$ \\
\hline I would visit La & Strongly disagree & 4.0 & 2.2 \\
Serena again & Disagree & 1.0 & 3.1 \\
& Undecided & 2.5 & 1.5 \\
& Agree & 29.7 & 30.2 \\
& Strongly agree & 62.7 & 63.1 \\
\hline I would & Strongly disagree & 3.7 & 2.2 \\
recommend & Disagree & 0.8 & 2.2 \\
visiting & Undecided & 3.5 & 3.7 \\
La Serena & Agree & 28.7 & 27.4 \\
& Strongly agree & 63.2 & 64.6 \\
\hline I'm satisfied & Strongly disagree & 3.9 & 2.2 \\
with my visit to & Disagree & 1.0 & 2.5 \\
La Serena & Undecided & 3.5 & 2.2 \\
& Agree & 28.1 & 31.4 \\
& Strongly agree & 63.5 & 61.8 \\
\hline
\end{tabular}

Source: Prepared by the authors.

The correlational analysis between the attributes of value and the general satisfaction of the tourist (Table 6) revealed for domestic and foreign tourists a strong relationship between the three dimensions examined $(p<.01)$. Therefore, we can expect a satisfied tourist would repeat the trip and recommend visiting the city.
Table 6: Pearson Correlation Analysis for satisfaction dimensions

\begin{tabular}{lllll}
\hline Origin & Dimension & Repetition & $\begin{array}{l}\text { Recommen } \\
\text {-dation }\end{array}$ & $\begin{array}{l}\text { Satisfac } \\
\text {-tion }\end{array}$ \\
\hline \multirow{2}{*}{ National } & Repetition & 1 & 0.904 & 0.892 \\
& Recommendation & 0.904 & 1 & 0.886 \\
& Satisfaction & 0.892 & 0.886 & 1 \\
\cline { 2 - 5 } Foreign & Repetition & 1 & 0.889 & 0.866 \\
& Recommendation & 0.889 & 1 & 0.869 \\
& Satisfaction & 0.866 & 0.869 & 1 \\
\hline
\end{tabular}

Source: Prepared by the authors.

On the other hand, the examination of satisfaction levels according to the sociodemographic characteristics of the sample, determined that in the case of national tourists there are significant differences between the level of income with the desire to repeat the visit $[F(4,590)=3.271$, $\mathrm{p}=.011]$, recommendation of the tourist destination [F (4, $590)=3.141, p=.014]$ and general perceived satisfaction $[F(4,590)=3.559, p=.007]$. Figure 3 illustrates globally that people with the lowest income (income below CLP $700,001)$ show more favorable responses (agree or strongly agree).

For foreign tourists, a significant difference was just revealed between the recommendation to visit the city and the level of income $[F(4,320)=2.421, p=.049]$, where tourists who have a favorable opinion are in the low income level (up to CLP 700,000) and those who demonstrate an unfavorable opinion are in the high income level (over CLP $1,200,000$ ). Check Figure 4. For the rest of the variables (sex, age, educational level and profession) there are not statistically relevant differences ( $5 \%$ significance) were reported.

Therefore, it is concluded that both domestic and foreign tourists are mostly satisfied with their visit to the city of La Serena, cheering to repeat the trip and willing to recommend the city as a tourist destination. However, it is noted that higher income visitors (national and foreign) have a more critical valuation of the city (less favorable) which would be linked to the requirement of higher performance standards (higher expectations). This situation is striking if it is considered that one of the issues for the Coquimbo 
Region, in the tourism field, is that it fails to capturing an optimal level of expenditure in relation to other international tourist destinations such as Brazil or Peru (Servicio Nacional de Turismo, 2017b, 2017a). Along these lines, the association test between the level of expenditure and income demonstrates a highly significant association, both for national tourists $[\chi 2(12, N=595)=117.03, p<.001]$ and foreigners $[\chi 2(12, N=325)=73.885, p<.001]$. So, it is revealed that the city would satisfy mostly whom spend less. It warns the local authorities and local businessmen to focus on conceiving a more attractive offer, as well as to raise the standards for the tourists with high-income.

Figure 3: Proportion of national tourists according to level of satisfaction, recommendation of destination and repeat visit $(n=595)$

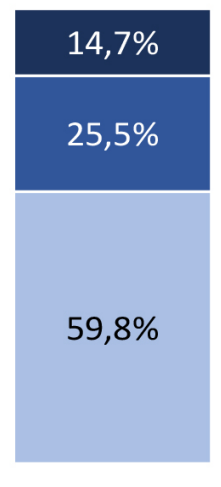

Yes

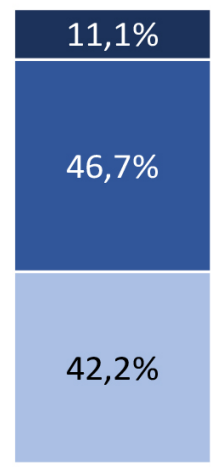

No

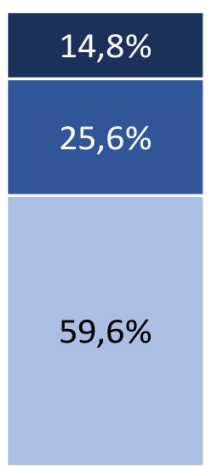

Yes

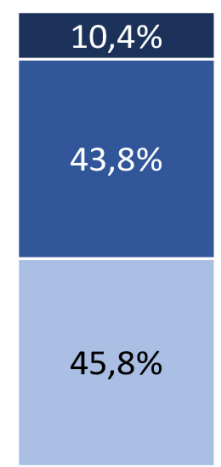

No

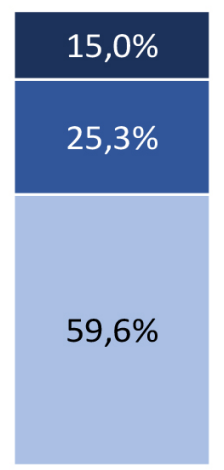

Yes

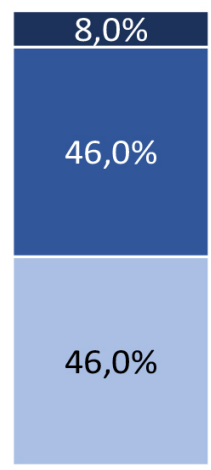

No

Repetition

Recommendation

Satisfaction

Low $(<$ CLP 700.001) $\quad$ Medium (700.001-1.200.000)

- High (> CLP 1.200.000)

Source: Prepared by the authors.

Figure 4: Proportion of foreign tourists according to income level and destination recommendation $(n=325)$

Yes recommended

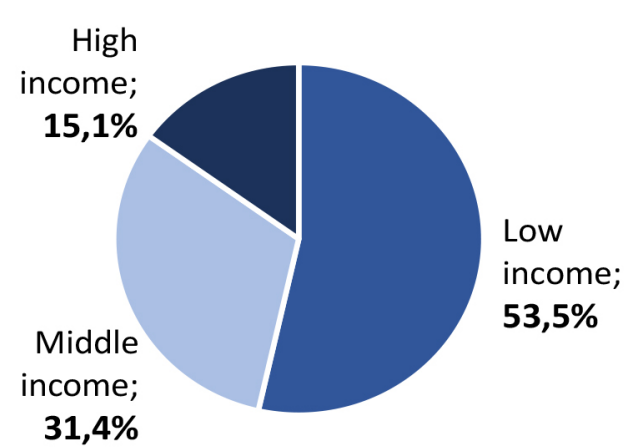

Not recommended

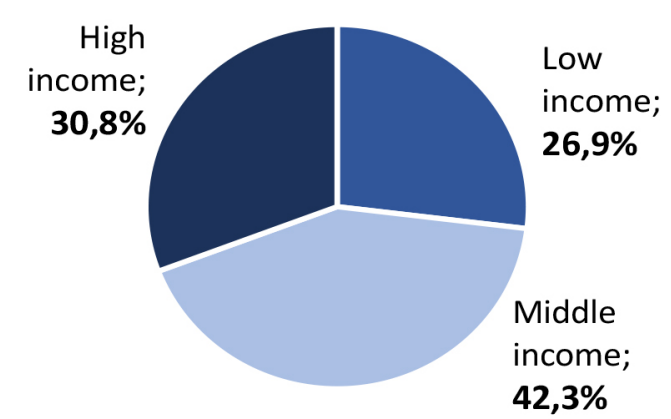

Source: Prepared by the authors. 


\section{Valuation of the attributes of the destination}

The results obtained from the valuation of the satisfaction attributes according to the origin of the tourist, were divided into three evaluation categories and four value attributes matching between national and foreign tourists: High (ranking 1 4), Medium (ranking 5 - 8) and Low (9 - 12). Check Table 7.

The previous results show that the best evaluated characteristics are the beauty of the city, the hospitality of the residents and the catering and local gastronomy services. It is followed by a second group, composed of the following attributes: attention and quality of tourist accommodation, citizen security, complementary entertainment and care-cleaning offer in the city. Finally, the third group consists of: public transport service, quality service of the tourist guides, available tourist information and quality-to-price ratio in the city.

From the above two relevant considerations were extracted.
The first one, the findings allow us to confirm those factors detailed by the literature as determinants for the motivation and satisfaction of the tourist and relevant for the destination La Serena and its tourist development. In other words, the beauty of the natural environment (De Uña-Álvarez, Cuquejo, \& Villarino, 2017), hospitality (Tomillo, 2013), gastronomy (Kido, Díaz, \& Kido, 2018; Oliveira, 2011; Pearson \& Pearson, 2017), security (Luders, Castillo, \& Gândara, 2016), cleaning (Benseny, 2006), transportation (Molina \& Arias, 2016), quality-to-price ratio (Solís-Radilla et al., 2016), accommodation (Fuentes, Hernández, \& Morini, 2016), restoration (Armijos, Bustamante, \& Calle, 2019), information and tourist guide (Zárraga, Corona, \& Molina, 2010). The second one, in regarding to the tourism system, the results provide a strategic direction in relation to the critical areas that should be considered to modify and, in this way, improve the perception of the tourist. Thus, it was evidenced the city of La Serena stands out positively in the

\section{Table 7: Valuation of tourist destination attributes according to average and tourist evalua-} tion ranking

\begin{tabular}{|c|c|c|c|c|c|}
\hline \multirow[b]{2}{*}{ Valuation } & \multirow[b]{2}{*}{ Attributes } & \multicolumn{2}{|c|}{ National Tourist } & \multicolumn{2}{|c|}{ Foreign Tourist } \\
\hline & & Average & Ranking & Average & Ranking \\
\hline & Beauty of the city & 4.54 & 1 & 4.58 & 1 \\
\hline High & Diversity and quality of local gastronomy & 4.24 & 2 & 4.30 & 4 \\
\hline \multirow{2}{*}{ (Ranking 1-4) } & Hospitality of the residents & 4.23 & 3 & 4.38 & 2 \\
\hline & Service and quality of restaurants and bars & 4.20 & 4 & 4.34 & 3 \\
\hline \multirow{4}{*}{$\begin{array}{l}\text { Medium } \\
\text { (Ranking 5-8) }\end{array}$} & Service and quality of tourist accommodation & 4.04 & 5 & 4.26 & 5 \\
\hline & Citizen security & 3.97 & 6 & 4.12 & 6 \\
\hline & Supplementary entertainment offer & 3.94 & 7 & 4.07 & 8 \\
\hline & Care and cleaning of the city & 3.92 & 8 & 4.08 & 7 \\
\hline \multirow{4}{*}{$\begin{array}{l}\text { Low } \\
\text { (Ranking 9-12) }\end{array}$} & Quality-to-price ratio & 3.86 & 9 & 3.92 & 11 \\
\hline & Tourist information & 3.76 & 10 & 3.97 & 9 \\
\hline & Service quality of tour guides & 3.69 & 11 & 3.96 & 10 \\
\hline & Public transport service & 3.58 & 12 & 3.69 & 12 \\
\hline
\end{tabular}

Source: Prepared by the authors.

The previous results show that the best evaluated characteristics are the beauty of the city, the hospitality of the residents and the catering and local gastronomy services. It is followed by a second group, composed of the following attributes: attention and quality of tourist accommodation, citizen security, complementary entertainment and care-cleaning offer in the city. Finally, the third group consists of: public transport service, quality service of the tou- rist guides, available tourist information and quality-to-price ratio in the city.

From the above two relevant considerations were extracted. The first one, the findings allow us to confirm those factors detailed by the literature as determinants for the motivation and satisfaction of the tourist and relevant for the destination La Serena and its tourist development. In 
other words, the beauty of the natural environment (De Uña-Álvarez, Cuquejo, \& Villarino, 2017), hospitality (TomiIlo, 2013), gastronomy (Kido, Díaz, \& Kido, 2018; Oliveira, 2011; Pearson \& Pearson, 2017), security (Luders, Castillo, \& Gândara, 2016), cleaning (Benseny, 2006), transportation (Molina \& Arias, 2016), quality-to-price ratio (Solís-Radilla et al., 2016), accommodation (Fuentes, Hernández, \& Morini, 2016), restoration (Armijos, Bustamante, \& Calle, 2019), information and tourist guide (Zárraga, Corona, \& Molina, 2010). The second one, in regarding to the tourism system, the results provide a strategic direction in relation to the critical areas that should be considered to modify and, in this way, improve the perception of the tourist. Thus, it was evidenced the city of La Serena stands out positively in the entire world due to its beauty, hos- pitality of residents, gastronomy, security and cleanliness. And, less favorable, the public transport service and the quality-to-price ratio. In regarding to the tourist offer, the restaurants, accommodation and complementary entertainment offer stand out positively. On the other hand, the tourist information provided and the quality of the tourist guides have an unfavorable influence.

Additionally, the application of the average tests revealed the existence of significant differences between national and foreign tourist related to Hospitality of residents, Service and quality of restaurants and bars, Service and quality of tourist accommodation, Citizen security, care and cleaning of the city, supplementary entertainment offer, tourist information and service of the tourist guides (Table 8).

Table 8: Tests of normality, equality of variances and equality of means for the valuation of the attributes of the destination

\begin{tabular}{|c|c|c|c|c|c|c|c|}
\hline \multirow[b]{2}{*}{ Items of the questionnaire } & \multirow[b]{2}{*}{ Origin } & \multicolumn{2}{|c|}{ Normality Test } & \multicolumn{2}{|c|}{ Equality of variances } & \multicolumn{2}{|c|}{ Equality of means } \\
\hline & & $\begin{array}{l}\text { K-S } \\
\text { Test }\end{array}$ & $\begin{array}{l}\mathrm{P} \\
\text { Value }\end{array}$ & $\begin{array}{l}\text { Levene } \\
\text { Test }\end{array}$ & $\begin{array}{l}P \\
\text { Value }\end{array}$ & $\begin{array}{l}\mathrm{T} \\
\text { Test }\end{array}$ & $\begin{array}{l}\mathbf{P} \\
\text { Value }\end{array}$ \\
\hline \multirow{2}{*}{ Beauty of the city } & National & 0.386 & 0.000 & 0.163 & 0.686 & 1.120 & 0.263 \\
\hline & Foreign & 0.366 & 0.000 & & & & \\
\hline \multirow{2}{*}{ Hospitality of the residents* } & National & 0.310 & 0.000 & 9.092 & 0.003 & 2.939 & 0.003 \\
\hline & Foreign & 0.266 & 0.000 & & & & \\
\hline \multirow{2}{*}{ Diversity and quality of local gastronomy } & National & 0.270 & 0.000 & 0.293 & 0.588 & 1.043 & 0.297 \\
\hline & Foreign & 0.250 & 0.000 & & & & \\
\hline \multirow{2}{*}{ Service and quality of tourist accommodation } & National & 0.257 & 0.000 & 0.176 & 0.675 & 3.707 & 0.000 \\
\hline & Foreign & 0.274 & 0.000 & & & & \\
\hline \multirow{2}{*}{ Service and quality of restaurants and bars } & National & 0.289 & 0.000 & 0.892 & 0.345 & 2.595 & 0.010 \\
\hline & Foreign & 0.258 & 0.000 & & & & \\
\hline \multirow{2}{*}{ Quality-to-price ratio } & National & 0.288 & 0.000 & 2.328 & 0.127 & 1.093 & 0.275 \\
\hline & Foreign & 0.270 & 0.000 & & & & \\
\hline \multirow{2}{*}{ Care and cleaning of the city } & National & 0.228 & 0.000 & 0.199 & 0.656 & 2.737 & 0.006 \\
\hline & Foreign & 0.248 & 0.000 & & & & \\
\hline \multirow{2}{*}{ Citizen security } & National & 0.259 & 0.000 & 1.863 & 0.173 & 2.664 & 0.008 \\
\hline & Foreign & 0.260 & 0.000 & & & & \\
\hline \multirow{2}{*}{ Service of the tour guides } & National & 0.270 & 0.000 & 0.520 & 0.471 & 3.730 & 0.000 \\
\hline & Foreign & 0.265 & 0.000 & & & & \\
\hline \multirow{2}{*}{ Tourist information } & National & 0.292 & 0.000 & 0.334 & 0.564 & 2.991 & 0.003 \\
\hline & Foreign & 0.268 & 0.000 & & & & \\
\hline \multirow{2}{*}{ Supplementary entertainment offer } & National & 0.254 & 0.000 & 0.190 & 0.663 & 2.084 & 0.037 \\
\hline & Foreign & 0.256 & 0.000 & & & & \\
\hline \multirow{2}{*}{ Public transport service } & National & 0.232 & 0.000 & 0.608 & 0.436 & 1.465 & 0.143 \\
\hline & Foreign & 0.231 & 0.000 & & & & \\
\hline
\end{tabular}

\footnotetext{
* T test for difference of means of unequal variances Source: Prepared by the authors.
} 
In this way, the findings show, ignoring the origin of the tourist, that the beauty of the city and the diversity and quality of the local gastronomy are the preferred attributes of the visitors, while the public transport service and the quality-to-price ratio of the area reveals a less favorable appreciation. On the other hand, considering the significant differences between the type of tourists, the other attributes were always valued better by foreign tourists.

Finally, the chi-square independence test was applied between the attributes of value and the general satisfaction of the tourist, revealing, for the national tourist, a significant association with: the beauty of the city $[\chi 2(3, N=595)=$ $17.23, p=0.001]$, the quality of tourist accommodation $[\chi 2$ $(4, \mathrm{~N}=595)=18.82, \mathrm{p}=0.001]$ and the complementary leisure offer $[\chi 2(4, N=595)=20.11, p<.001]$. While for the foreign tourist, significant associations were revealed between the level of satisfaction with: the beauty of the city $[\chi 2(4, N=325)=14.48, p=0.006]$, the hospitality of the residents $[\chi 2(3, N=325)=14.99, p=0.002]$, local gastronomy $[\chi 2(4, N=325)=10.45, p=0.033]$, the quality of tourist accommodation $[\chi 2(4, N=325)=13.48, p=0.009]$, the quality-to-price ratio $[\chi 2(4, N=325)=13.69, p=0.008]$ and the complementary entertainment offer $[\chi 2(4, N=325)=$ $15.54, p=0.004]$. Thus, I would highlight that to achieve higher levels of satisfaction, special emphasis should be placed on improving each of those factors mentioned above.

\section{CONCLUSIONS}

Based on the analysis of the results of the study, it's concluded that the national tourist who visits the city of La Serena has a homogeneous demographic profile in terms of sex and age, presenting only relevant differences in relation to the socioeconomic level (education, income and profession), higher on the part of foreign tourists.

Also, the analysis of behavioral aspects revealed significant differences between the characteristics of tourists according to their origin, where it was determined that foreign visitors, unlike nationals, are more influenced in their travel decision (motivation) on the internet and social networks, plan a longer stay, have higher spending levels, mostly host hotels and hostels for your stay (instead of renting houses or apartments), plan their trip in advance and use more internet as a means of information and commerce (contracting online services).

The examination of the motivational aspects of national and foreign tourists showed a coincidence between the main motivation of travel (disconnecting from everyday life) and the less relevant ones (attending cultural events and knowing their historical wealth). The main differences occurred in foreign tourists since they are more motivated to know new places and national tourist looks to take advantage of economic accessibility. In this way, it is concluded that the national tourist travels to the city of La Serena with the aim of disconnecting from the traditional, taking advantage of its economic convenience and because of the tourist reputation of the city. While international tourist visits the city to disconnect from the everyday, with the desire to know new places and also, for the tourist reputation.

The study also highlighted the low interest in knowing the historical wealth of the city and attending cultural events which is discordant with the traditional image of La Serena since as a tourist destination seeks distinction to establish itself, particularly, for the attractiveness represented in its cultural historical heritage.

For its part, the review of the level of visitor satisfaction determined that both types of tourists are mostly satisfied visiting La Serena with the intention of repeating their trip and willing to recommend the city as a tourist destination. However, it is also revealed that higher income visitors (both domestic and foreign) have a more critical valuation of the city (less favorable). Thus, it is noted that the city would satisfy mostly those who spend less and therefore, imposes the challenge for local authorities and local businessmen to design a more attractive offer, as well as raise the standards for the tourist who can spend more (higher income). In this way, Alegre \& Garau (2011), stand out as the attribute of greater predictive power of repeating visit of a tourist destination to the offer of variety of tourist products. $\mathrm{n}$ this way, it would be expected that as a destination incorporates a greater portfolio of tourism products and services, the level of satisfaction increases.

Otherwise, the findings show, regardless of the origin of the tourist, three groups of valuation attributes of the tourist destination. A first category (high valuation) composed of the attributes: beauty of the city, hospitality of residents and catering and local gastronomy services. A second group (average valuation), composed of the attributes: attention and quality of tourist accommodation, citizen security, complementary entertainment offer and care-cleaning of the city. Finally, a third group (low valua- 
tion) composed of: public transport service, service of the tourist guides, available tourist information and quality-to-price ratio in the city. Therefore, it would be expected that the attention of the detected factors will be effective improving the visitor experience and also, increasing the quality of the service delivered and therefore, the tourist's perceived value (more favorable relationship between the perceived benefits and transaction costs).

Finally, for future researches it is suggested to replicate the study in order to corroborate the findings obtained and measure their evolution over time (longitudinal approach), as well as analyze the determinants of satisfaction from a multivariate perspective that allows identifying those factors that increase the probability of satisfaction or repetition of the visit, as well as those variables that influencing (strong association) it. Otherwise, it would be interesting to address further the impact or influence of the use of Internet resources on tourist behavior especially if it is considered their wide use among visitors keeping in mind that the main deficiencies are related to quality of the information provided.

\section{REFERENCES}

Alegre, J., \& Garau, J. (2011). The factor structure of tourist satisfaction at sun and sand destinations. Journal of Travel Research, 50(1), 78-86. https://doi. org/10.1177/0047287509349270.

Araújo, G., \& De Sevilha, M. (2017). Los viajeros y sus motivaciones. Un estudio exploratorio sobre quienes aman viajar. Estudios y Perspectivas En Turismo, 26(1), 62-85. Retrieved from https://www.redalyc.org/ pdf/1807/180749182004.pdf

Armijos, J., Bustamante, J., \& Calle, M. (2019). Percepción del turista sobre el servicio de alimentos y bebidas. Sitio, Playa Bajoalto, Cantón El Guago, El Oro, Ecuador. Revista Interamericana de Ambiente y Turismo - RIAT, 15(1), 93-101. Retrieved from https://scielo.conicyt.cl/pdf/ riat/v15n1/0718-235X-riat-15-01-93.pdf

Benseny, G. (2006). El espacio turístico litoral. Aportes y Transferencias, 10(2), 102-122. Retrieved from https:// www.redalyc.org/pdf/276/27610208.pdf

Biblioteca del Congreso Nacional de Chile. (2017). Reporte Estadístico Comunal 2017 La Serena. Retrieved from https://reportescomunales.bcn.cl/2017/PDF/La_ Serena.pdf

De Uña-Álvarez, E., Cuquejo, M. del C., \& Villarino, M. (2017). Valoración local del patrimonio natural para el desarrollo turístico en un territorio rural transfronterizo (Sierra del Larouco, Galicia-Norte de Portugal). Papeles de Geografía, 63(63), 181. https://doi.org/10.6018/geografia/2017/293271

Fernández, G., \& Narváez, M. (2012). Satisfacción de los turistas en el destino Península de Paraguaná, estado Falcón. Multiciencias, 12, 324-330. Retrieved from http:// www.redalyc.org/articulo.oa?id=90431109053

Fuentes, M., Hernández, E., \& Morini, S. (2016). Q de calidad y satisfacción del turista en el sector hotelero español. Cuadernos de Turismo, (37), 203-226. Retrieved from http://www.redalyc.org/articulo.oa?id=39845353009

Hidalgo-Alcázar, C., Sicilia, M., \& De Maya, S. R. (2015). La imagen de un producto turístico rural a través del acceso al contenido generado por otros usuarios en internet: Diferencias por género. Journal of Technology Management and Innovation, 10(3), 75-84. https://doi. org/10.4067/S0718-27242015000300009

Kido, M. T., Díaz, I., \& Kido, A. (2018). La satisfacción del comensal como elemento clave del binomio gastronomía-turismo en Tijuana. Estudios Sociales, 51(28), 1-25. https://doi.org/10.24836/es.v28i51.499

Levy, A., \& Arce, N. (2016). Destinos Turísticos Consolidados de Chile: Antecedentes Básicos para la Gestión Turística (p. 228). p. 228. Retrieved from https://www.sernatur.cl/ wp-content/uploads/2018/10/Destinos-Turísticos-Consolidados-2016-Antecedentes-básicos-para-la-inversión.pdf

López, A. L., Verdesoto, E., \& López, A. (2017). Turismo 2.0 como herramienta para promocionar los atractivos culturales de Guayaquil. INNOVA Research Journal, 2(6), 154163. https://doi.org/10.33890/innova.v2.n6.2017.299

Luders, D., Castillo, M., \& Gândara, J. (2016). La Influencia de la Seguridad Pública en la Satisfacción y en la Formación de la Imagen de Curitiba (Brasil) para el Visitante y los Visitados. Estudios y Perspectivas En Turismo, 25(4), 416-438. Retrieved from http://www.redalyc.org/articulo.oa?id=180747502002 
Molina, V. C., \& Arias, A. V. (2016). El papel del transporte en el desarrollo de la actividad turística: Un análisis bibliométrico. Revista Geografica Venezolana, 57(2), 278295. Retrieved from https://www.redalyc.org/articulo. oa?id=347750606007

Morales, J. R., Arévalo, D. X., Padilla, C. P., \& Bustamante, M. A. (2018). Nivel de Satisfacción e Intención de Repetir la Visita Turística. El Caso del Cantón Playas, en Ecuador. Información Tecnológica, 29(1), 181-192. https:// doi.org/10.4067/s0718-07642018000100181

Muñoz, G., Carvache-Franco, W., Torres-Naranjo, M., \& López-Guzmán, T. (2018). Análisis del perfil sociodemográfico y de las motivaciones del turista que visita Quito, Ecuador. Innovar, 28(68), 77-90. https://doi.org/10.15446/ innovar.v28n68.70473.enlace

Oliveira, B. (2011). Determinantes de la Satisfacción del Turista. Estudios y Perspectivas En Turismo, 20(1), 229-242. Retrieved from https://www.redalyc.org/ pdf/1807/180717677013.pdf

Oliveira, S. (2011). La gastronomía como atractivo turístico primario de un destino: El Turismo Gastronómico en Mealhada - Portugal. Estudios y Perspectivas En Turismo, 20(3), 738-752. Retrieved from https://pdfs. semanticscholar.org/ff89/77d3d689f4faae243e3c07d4822412f1fdfa.pdf

Orgaz, F., \& Moral, S. (2016). El turismo como motor po- tencial para el desarrollo económico de zonas. El Periplo Sustentable, (31). Retrieved from https://www.mendeley. $\mathrm{com} /$ viewer/?fileld=49a39429-08d1-28b9-01 cb-c36d29 9a1511\&documentld=187cf38f-48cb-3c1b-8e0a-864a0 $1 \mathrm{c} 7 \mathrm{a} 735$

Osuna, M., Castillo, A. M., \& López-Guzmán, T. (2011). Turismo y desarrollo económico. Un análisis de la isla de Santiago (Cabo Verde). Turismo y Desarrollo Socioeconómico. Un Análisis de La Isla de Santiago (Cabo Verde). Turismo y Desarrollo Económico: IV Jornadas de Investigación En Turismo, 519-535. Retrieved from https://idus.us.es/ xmlui/bitstream/handle/11441/53094/osuna-castillo. pdf?sequence $=1$ \&isAllowed $=y$

Pearson, D., \& Pearson, T. (2017). Branding Food Culture: UNESCO Creative Cities of Gastronomy. Journal of Food Products Marketing, 23(3), 342-355. https://doi.org/10.1 080/10454446.2014.1000441

Sandoval, D., Ordoñez, O., \& Noblecilla, M. (2018). Percepción del perfil del turista para el aprovechamiento de los atractivos turísticos: Caso Cantón Pasaje, El Oro (Ecuador). Revista Interamericana de Ambiente y Turismo, 14(1), 14-21. https://doi.org/10.4067/s0718$235 \times 2018000100014$

Schulte, S. (2003). Guía conceptual y metodológica para el desarrollo y la planificación del sector turismo. In Publicación de las Naciones Unidas (Vol. 25). https://doi. org/10.1513/AnnalsATS.201306-1440C 
SECPLAN. (2015). PLADECO 2015 - 2018. Actualización 2016.

Servicio Nacional de Turismo. (2017a). Anuario de turismo 2016. Retrieved from https://www.sernatur.cl/ wp-content/uploads/2018/09/20170731-ANUARIO-TURISMO-2016-julio.pdf

Servicio Nacional de Turismo. (2017b). Manual de Diseño Experiencias Turísticas. Retrieved from https://www. sernatur.cl/wp-content/uploads/2018/11/MDD-Manual-de-Experiencias-Turísticas-1.pdf

Servicio Nacional de Turismo. (2018a). Destino La Serena (p. 26). p. 26. Retrieved from http://turismoregiondecoquimbo.cl/wp-content/uploads/2019/05/Destino-La-Serena-español.pdf

Servicio Nacional de Turismo. (2018b). Informe de intensidad turística y definición de destinos turísti$\cos$ (2018) (p. 57). p. 57. Retrieved from http://www. subturismo.gob.cl/wp-content/uploads/2015/09/ Informe-de-Intensidad-Turística-y-Definición-de-Destinos-Turísticos-2018-1.pdf

Solís-Radilla, M. M., Hernández-Lobato, L., \& Villagómez-Méndez, J. (2016). El Valor Percibido del Destino Turístico en Relación con el Perfil del Turista en Acapulco, Guerrero-México. Investigación Administrativa, 46(118), 1-27. Retrieved from http://www.scielo.org.mx/pdf/ia/ v45n118/2448-7678-ia-45-118-00002.pdf
Tomillo, F. (2013). La hospitalidad como condición necesaria para el desarrollo local. Revista Hospitdalidade, 10(2), 161-212. Retrieved from https://revhosp.org/hospitalidade/article/view/530/541

Visión Humana. (2018). Barómetro Imagen ciudad Versión 2018 (p. 30). p. 30. Retrieved from http://visionhumana.cl/portfolio_page/informe-publico-barometro-imagen-ciudad-2018/

Weaver, P., Weber, K., \& Mccleary, K. (2007). Destination evaluation: The role of previous travel experience and trip characteristics. Journal of Travel Research, 45(3), 333344. https://doi.org/10.1177/0047287506292702

Webster, C., \& Ivanov, S. (2014). Transforming competitiveness into economic benefits: Does tourism stimulate economic growth in more competitive destinations? Tourism Management, 40, 137-140. https://doi.org/10.1016/j.tourman.2013.06.003

Yumisaca, J. E., Mendoza, A. E., \& Villón, S. G. (2017). Perfil Sociodemográfico Del Turista De La Provincia De Santa Elena En Ecuador.: Referencias Para Nuevas Propuestas De Desarrollo. Revista Universidad y Sociedad, 9(3), 52-59.

Zárraga, L., Corona, E., \& Molina, V. (2010). Las competencias de los guías turistas como ventaja competitiva en el sector turista: caso Cancún Quintana Roo. Revista Internacional Administración \& Finanzas, 3(3), 11-25. Retrieved from https:// papers.ssrn.com/sol3/papers.cfm?abstract_id=1881174 